\section{David Salway}

David Salway was born and raised in Bristol. He attended Bristol and Reigate Grammar Schools and Newcastle Dental School, graduating in 1966. He was extremely proud of his Newcastle qualification and it was while he was a student there that he met his wife, Marian. His forté was children's dentistry to which he dedicated his career,

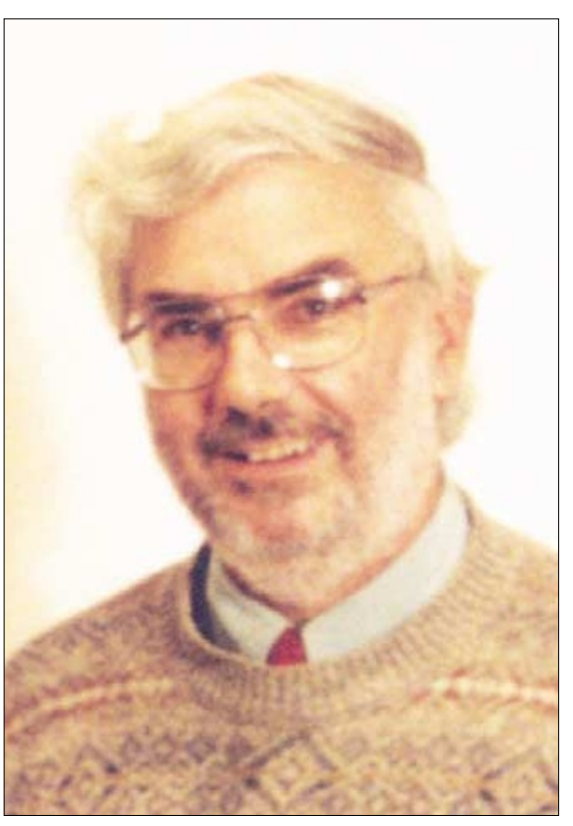

joining the schools service in Barnard Castle, County Durham. He and Marian moved to the Furness area of Cumbria in 1976 on his promotion to District Dental Officer. He became senior dental officer for the South Cumbria Community and Mental Health NHS Trust and prior to his death, Medical and Dental Director of Bay Community NHS Trust.

When David came to the Morecambe Bay area, the old Barrow Section of the BDA was languishing in the doldrums. Together with Jack Guest, the Section was resurrected, revitalised and renamed the Furness and South Cumbria Section. David served as Secretary for several years and latterly as its Chairman. In 1991, he became the North Western Branch treasurer remaining in charge of its finances until his death. David was indefatigable in his regular attendance at Section, Conjoint and Branch Council meetings. He was honoured for his services to the Branch when he became its President in 1990.

David tutored dental nurses in Durham and was an examiner for the National Examining Boa rd for Dental Nurses for over 20 years. He was an active member of the British Fluoridation Society and the
British Dental Migraine Study Group.

In addition to his skill as a clinician, he was an accomplished cook and skilful doit-yourselfer. He was an enthusiastic gardner, and an active committee member of the local Horticultural Society. He had also served the village community by being chairman of the school PTA and a member of the Playground Committee.

He died on February 7, 2000, just two weeks after his 58th birthday after a bravely fought battle with a malignant melanoma, which had been first diagnosed in the retina of his right eye. Typically his interest after the loss of the eye was not centred on self pity but on the technical problems related to the impression taking and con struction of his replacement prosthesis.

David was the epitome of the true professional but above all he was a gentleman and he will be greatly missed. He was a member of the Society of Friends and his funeral, a Quaker service, drew the largest number of people at a service at Barrowin-Furness crematorium to date.

To his wife, Marian, and his daughters, Anne and Catherine, we extend our deepest sympathies.

M.I.H

\section{Harry Carter}

Harry (Nick) Carter was born in 1922 at St Thomas's Hospital, London and educated at The Roan School, Blackheath. As war was looming, he joined the RAF as a pilot and was drafted into Bomber Command. Due to an oversight, he was discovered to be colour-blind and he was moved sideways to became an instructor on 156 Squadron, Pathfinder Force. He attained the rank of Flying Officer and eventually did fly over France, if only to drop leaflets after the Allied advance. It was during his Royal Air Force days that he met his wife Wendy.

After the war, the need for the Armed Forces diminished and Nick eventually enrolled at Guy's Hospital Dental School to become a dental surgeon. After qualifying, he moved to Hastings in 1952 to join the prestigious practice of Terence Ward (later to become Sir Terence) and Tom Cheevers, in their prominent seaside premises. Records show that he was an established member of the BDA Hastings, Bexhill and District Section and even note that during the financial year 1954/55 he paid the subscription of ten shillings and six pence!

He was always an active member of the Section and was instrumental in construct- ing the Jewel of the Section. Being immensely practical, he undertook the task himself, together with his technician and using scrap gold, cast this on the premises. He arranged for the jewel to be enamelled at the Hastings College of Arts and Technology by one of his patients.

He held the rank of Secretary, Treasurer and Chairman several times during his practising career. He was an accomplished speaker, especially at the famed Hastings' Section male dinner, now defunct, where his risque stories, often drawn from life, were always appreciated. He was a great supporter of his alma mater and used to attend Clinical Day at Guys, where he would meet his old student comrades and mull about old times.

When he retired and the need for clinical knowledge was reduced, he would still attend the social functions of the Section with Wendy. He was Church Warden of Crowhurst Parish Church for 17 years and became a lay Minister. He was also accomplished in the art of gardening, sketching and painting.

As the prostate cancer took hold over the last few years he had to curtail these activities, but there was always a warm welcome, a twinkle in his eye and a story upon meeting him. He died peacefully on April 28 2000. Wendy and their three daughters, twins Hilary and Dianne, and Sarah, survive him.

C.B.H

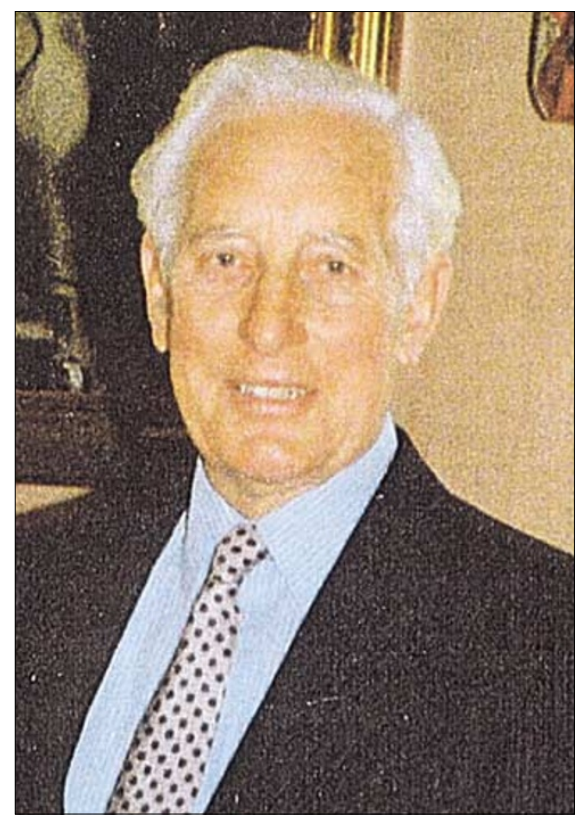

